\title{
Procuring Corpses: The English Anatomy Inspectorate, 1842 to 1858
}

\author{
HELEN MacDONALD*
}

\section{Introduction}

In September 1873, England's newspapers carried stories headlined 'Horrible Discovery in the Thames'. Parts of a woman's body had been found in the river over the course of several days and it was proving impossible to identify her. One of London's medical schools was rumoured to be the source of these mutilated remains. However, the Daily News reminded its readers that a law required the registration of bodies that were sent to a medical school to be dissected, and expressed the view that the metropolitan anatomy inspector was no doubt checking his register. As he was. Doing so enabled Inspector Charles Hawkins to assure the public that he had not authorized a corpse matching this woman's description to be sent to any school. Medical periodicals such as the Lancet and the British Medical Journal also published strenuous denials that this body had been dismembered in a London dissecting room. Although it appeared to have been dexterously cut, the Lancet claimed that it was absurd to suggest that medical students had done this, given the anatomy inspector's keen oversight of the British Anatomy Act, a statute that contained stringent requirements about how dissected remains must be buried. In these circumstances, it was simply not possible for a corpse to be so "ignominiously" treated and then "secretly disposed of" in the river. The British Medical Journal agreed. While parts of dissected bodies were sometimes retained for museums rather than being buried, the suggestion that these remains had emanated from a medical school was "altogether wild" and unworthy of a moment's attention. ${ }^{1}$

For the purpose of this article, the question of whether or not these particular remains had been thrown into the Thames to hide a murder, or as a medical student prank, or to empty out a dissecting room and save the cost of a burial before the beginning of the winter dissecting season, is irrelevant. What matters is that when remains like these were found, the immediate popular reaction was to assume that they had come from one of London's medical schools, despite the existence of the Anatomy Act and what appeared to be its stringent requirements. In this article, which explores the workings of England's anatomy inspectorate between 1842 and 1858, I argue that the inspectorate was under-resourced, and increasingly became embroiled in unlawful and unethical ways

(c) Helen MacDonald 2009

*Helen MacDonald, MA, PhD, The Australian Centre, School of Historical Studies, University of Melbourne, 3010, Victoria, Australia; e-mail: h.macdonald@unimelb.edu.au

I am grateful to the Australian Research Council for supporting this research through a postdoctoral fellowship between 2005 and 2008. I should also like to thank the journal's anonymous referees for their constructive feedback on this article.

${ }^{1}$ Daily News, 8 Sept. 1873, and Birmingham Daily Post, 20 Sept. 1873, containing reprinted articles from the Lancet and the British Medical Journal. 


\section{Helen MacDonald}

of obtaining and distributing corpses for anatomical examination. An analysis of the anatomy legislation and the practices that arose under it also enables us to contemplate an historical example of a regime of presumed consent to an unpopular scientific use of the dead. At a time when there is a movement in England to institute presumed consent to organ and tissue donation, the discussion of such an historical example seems timely. $^{2}$

\section{The Legislative Framework}

In her now classic work, Death, dissection and the destitute (1987) Ruth Richardson explored the early nineteenth-century debates about how British medical schools should be supplied with corpses for their students to dissect. For a number of reasons, the issue had become urgent by the late 1820 s. The shortage of cadavers was so extreme that the grave-robbers who supplied many medical and anatomy schools were charging up to $£ 10$ for each fresh adult corpse, and recent court proceedings had resulted in medical men and students being found guilty of misdemeanours for having bodies in their possession. ${ }^{3}$ In 1828, a Select Committee on Anatomy reported to parliament, and its chairman Henry Warburton drafted an Anatomy Bill that would give the schools access to the unclaimed bodies of people who died in workhouses and hospitals. This first attempt to regulate anatomy failed to pass through the House of Lords. ${ }^{4}$ Within three years, however, the discovery that people were being murdered in Edinburgh and London so that their corpses could be sold to anatomy schools, led Warburton to introduce a new Anatomy Bill in $1831 .^{5}$

As Richardson has revealed, this was a tricky piece of legislation, from which Warburton had erased many of the problematic terms which had seen his earlier bill fail. The new draft was titled 'A Bill for Regulating Schools of Anatomy', though it would do no such thing. Instead, it enabled people to donate their own or their relatives' remains for anatomical examination, though given the public abhorrence of dissection no one taking part in the parliamentary debate actually envisaged donation becoming a major source of supply. ${ }^{6}$ More importantly therefore, the bill established a regime of presumed consent to dissection. It authorized certain parties to be in lawful possession of corpses for the purpose of disposing of them to medical schools, if the person had not, in life, formally registered their dissent to being dissected, and if no relatives claimed the

\footnotetext{
${ }^{2}$ Presumed consent to donation was extensively discussed in the English media following the release of the Organ Donation Taskforce's report, Organs for transplants: a report, London, Department of Health, in January 2008.

${ }^{3}$ These included, in $1828, R$. v. Gill in which a Liverpool surgeon was convicted and fined, and the trial of medical student John Davies in R. v. Davies et al., which resulted in a conviction at the Lancaster assizes.

${ }^{4}$ Henry Warburton, MP for Bridport, was the instigator of the Select Committee on Anatomy. For the failure of the 1829 Anatomy Bill, see Ruth Richardson, Death, dissection and the destitute, Harmondsworth, Penguin, 1988, p. 157.
}

\footnotetext{
${ }^{5}$ For the murders, see William Roughead (ed.), Burke and Hare, London, William Hodge, 1948; Sarah Wise, The Italian boy: murder and graverobbery in 1830s London, London, Jonathan Cape, 2004; Helen MacDonald, Human remains: dissection and its histories, New Haven, Yale University Press, 2006, pp. 23-7 (published in Australia as Human remains: episodes in human dissection, Carlton, Melbourne University Press, 2005).

${ }^{6}$ For the ways in which dissection contravened social mores about how corpses should be treated, see Richardson, op. cit., note 4 above, pp. 3-29.
} 


\section{The English Anatomy Inspectorate, 1842 to 1858}

body for burial within forty-eight hours of the death. The bill failed to specify who these powerful parties would be, but they were envisaged as the men who were in positions of authority in places where large numbers of poor people died, especially workhouses and hospitals. ${ }^{7}$ Undertakers were specifically excluded from having such a role. Their only lawful activity with the dead was to carry them to the school, and six weeks later bury the remains in a decent coffin or shell. Finally, and most importantly for this article, the Anatomy Bill established an inspectorate to deal with all the paperwork involved, and visit the schools from time to time.

Despite opposition, this bill passed through parliament in 1832. Two Englishmen, John Bishop and Thomas Williams, had just been hanged for committing murder in order to obtain corpses to sell to London medical schools. In the face of their market solution to the shortage of cadavers, any legitimated means of supply seemed preferable. One of the bill's critics, Lord Teynham, made a last ditch stand in parliament, claiming that as the legislation failed to ban the sale of corpses it would "convert every workhousekeeper into a systematic trafficker in dead bodies". 8 However it would be another twenty-five years before the public learned the prescience of that prediction.

\section{The Anatomy Inspectorate}

A close reading of the parliamentary debate of 1831-2 reveals that much uncertainty existed about the imagined focus of Britain's anatomy inspectorate. This was hardly surprising, since it was the first of what became a series of Victorian inspectorates. ${ }^{9}$ Each of these differed according to the legislation under which it was established, the activities it monitored, and whether or not it fell under the jurisdiction of the Home Office. However, as P W J Bartrip and Felix Driver have argued, some commonalities existed. These inspectorates were government funded, with nationwide powers to supervise at least to some degree, the institutions that were regulated by the legislation. They were also staffed by salaried specialists with a remit to give effect to these statutes, which made them unprecedented. ${ }^{10}$

\footnotetext{
${ }^{7}$ Over subsequent years, corpses were also obtained from places in which people were confined: jails, houses of correction, prison hulks and asylums. The hulks were a favoured source of supply, as those who died on them were relatively young and they made good subjects for dissection (Richardson, op. cit., note 4 above, p. 248).

${ }^{8}$ Hansard Parliamentary Debates (hereafter Parl. Debs (series 3), vol. 14, col. 534, 3 July to 16 Aug. 1832 (on 19 July 1832).

${ }^{9}$ In chronological order, these were anatomy (1832), factories (1833), lunacy (1833), emigration (1833), poor law (1834), prisons (1836), tithe commutation (1836), education (1839), railways (1840), mines (1842), public health / local government (1848), mercantile marine (1850), charities (1853), juvenile reformatories (1854), burial grounds (1855), police (1856), vaccination (1861), salmon fisheries (1861), alkali works (1863), oyster
}

and mussel fisheries (1866), contagious diseases in animals (1869), explosive substances (1875), and cruelty to animals (1876), see P W J Bartrip, 'British government inspection, 1832-1875: some observations', Hist. J., 1982, 25: 605-26, p. 607. See also, Jill Pellew, The Home Office 1848-1914: from clerks to bureaucrats, London, Heinemann

Educational Books, 1982, p. 122; Christine Garwood, 'Green crusaders or captives of industry? The British alkali inspectorate and the ethics of environmental decision making, 1864-95', Ann. Sci., 2004, 61: 99-117; and Tom Crook, 'Sanitary inspection and the public sphere in late Victorian and Edwardian Britain: a case study in liberal governance', Soc. Hist., 2008, 32: 369-93.

${ }^{10}$ Bartrip, op. cit., note 9 above, p. 606, and Felix Driver, Power and pauperism: the workhouse system 1834-1884, Cambridge University Press, 1993, p. 28. 


\section{Helen MacDonald}

During the parliamentary debate on anatomy, the bill's critics had envisaged the inspectors as playing a major role, specifically to protect people from being dissected against their own or their relatives' wishes, and to ensure that the parties who were in lawful possession of corpses acted according to the law. The critics had therefore argued that the inspectors should have extensive investigatory powers, even to examine all bodies prior to their dissection in order to ensure that none had been surreptitiously obtained. ${ }^{11}$ They had also tried to insist that no medical man who had a direct interest in dissecting a specific corpse, should have the power to sign the certificate that made it available for this purpose. ${ }^{12}$ Finally, the bill's critics had argued that the inspectors should have the authority to prosecute cases when they discovered anything wrong, given that poor people whose relatives were "improperly made away with" would be unable to afford to mount a legal prosecution. ${ }^{13}$ In contrast, the bill's defenders wanted the inspectors' role to be minimal. They spoke of the inspectorate as being merely a precautionary measure. Warburton advocated leaving the specifics of the role to the Secretary of State, to whom the inspectors would report. ${ }^{14} \mathrm{He}$ tried to claim that the inspectors' duties could be performed throughout Britain by just one man "with the assistance of some policemen". ${ }^{15}$ Others strongly disagreed. They argued that one inspector would hardly be adequate efficiently to superintend this Act, and that the salary of $£ 100$ per annum was insufficient for the "constant attention" to his duties that would be required. $^{16}$

Once the Act had been passed, three inspectors were initially appointed, one for Scotland, one for England and Wales and one for Ireland. The inspector was to process the applications for licences to perform anatomical examinations that arrived in the office, receive notices and certificates relating to unclaimed corpses, record these in a book, and make quarterly returns to the Secretary of State. He was also to visit and inspect places in which it was intended to practise anatomy. Interestingly for what follows, a certain degree of secrecy was built into the role from the beginning. The inspectors' salaries were to be paid from the consolidated fund rather than directly from parliament. This removed the expenditure from parliament's budget process and avoided "an annual discussion on this delicate subject" which, it was envisaged, might lead to "increased difficulty $\ldots$ in procuring bodies". ${ }^{17}$

Compared with the other Victorian inspectorates established after 1832, the anatomy inspectors' role was indeed limited. The remit of the assistant commissioners who were appointed under the Poor Law Amendment Act two years later, for example, was highly interventionist in comparison. As Poor Law historians have shown, these "young crusaders" initially found themselves responsible for organizing the new unions throughout Britain, enforcing the unpopular workhouse test, banning outdoor relief, aiding Guardians to select personnel, and regularly monitoring union operations thereafter. ${ }^{18}$

\footnotetext{
${ }^{11}$ Parl. Debs. (series 3), vol. 10, col. 836, 7 Feb. to 8 Mar. 1832 (on 27 Feb. 1832); vol. 12, cols. 667-68, 9 Apr. to 23 May 1832 (on 18 Apr. 1832).

${ }^{12}$ Parl. Debs. (series 3), vol. 10, col. 833, 27 Feb. 1832; col. 667, 18 Apr. 1832.

${ }^{13}$ Parl. Debs. (series 3), vol. 12, col. 313, 11 Apr. 1832.
}

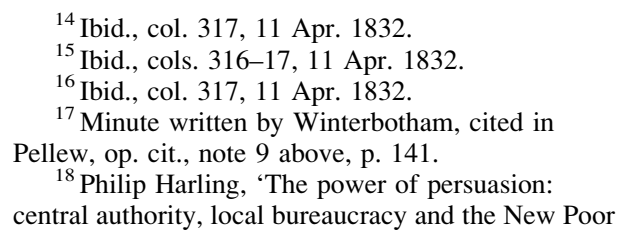

${ }^{17}$ Minute written by Winterbotham, cited in Pellew, op. cit., note 9 above, p. 141.

${ }^{18}$ Philip Harling, 'The power of persuasion: central authority, local bureaucracy and the New Poor 


\section{The English Anatomy Inspectorate, 1842 to 1858}

Nevertheless, as Jill Pellew has argued, given how under-resourced all the Victorian inspectorates were, it was remarkable that they achieved much at all. Those which reported to the Home Office often lacked direction, and successive Secretaries of State took varying degrees of interest in their work. ${ }^{19}$ In effect, the inspectorates were charged with putting into practice regulative laws while lacking the resources and authority required for state intervention of this kind. ${ }^{20}$

\section{The Anatomy Inspectorate's First Decade}

James Somerville and David Craigie were appointed the anatomy inspectors for England and Wales, and Scotland respectively, in 1832. ${ }^{21}$ Michael Durey and Ruth Richardson have both examined Somerville's decade as England's inspector. ${ }^{22}$ Somerville designed a system of certificates, notices and warrants to enable him to track the movement of

Law', Eng. Hist. Rev., 1992, 107: 30-53, p. 31. The assistant commissioners were called inspectors after 1842 , and their role also changed over time.

${ }^{19}$ Pellew, op. cit., note 9 above, pp. 146-7. The Home Office, and individual Secretaries of State, were also increasingly overworked as this era of legislative change progressed (A P Donajgrodzki, 'Sir James Graham at the Home Office', Hist. J., 1977, 20: 97-120).

${ }^{20}$ For a discussion focusing on two of the industrial inspectorates established under factory and mines legislation, see P W J Bartrip, 'State intervention in mid-nineteenth century Britain: fact or fiction?', J. Br. Stud., 1983, 23: 63-83.

${ }^{21}$ Dr James Craig Somerville had given evidence before the 1828 Select Committee on Anatomy, at which time he was Benjamin Brodie's assistant at the School of Anatomy in Windmill Street. In December 1836 Somerville became Britain's only anatomy inspector when his role was expanded to incorporate Scotland as well as England. A protégé of Henry Warburton, Somerville controversially became a member of the University of London Senate for a brief period in 1838 . He died in 1847 , five years after being dismissed from the inspectorate. Dr David Craigie, the Scottish inspector from 1832 until 1836, was a graduate of the University of Edinburgh, an elected physician at Edinburgh's Royal Infirmary, and a Fellow of Edinburgh's Royal College of Surgeons. For many years he edited the Edinburgh Medical and Surgical Journal.

${ }^{22}$ M J Durey, 'Bodysnatchers and Benthamites: the implications of the Dead Body Bill for the London schools of anatomy, 1820-42', Lond. J., 1976, 2: 200-25; Richardson, op. cit., note 4 above, pp. 239-60. Other historians exploring aspects of the history of human dissection in Britain during the nineteenth-century include Sean Burrell and Geoffrey Gill, 'The Liverpool cholera epidemic of 1832 and anatomical dissection: medical mistrust and civil unrest', J. Hist. Med. Allied Sci., 2005, 60: 478-98;
Elizabeth T Hurren, 'A pauper dead-house: the expansion of the Cambridge anatomical teaching school under the late-Victorian Poor Law, 1870-1914', Med. Hist., 2004, 48: 69-94; idem, 'Whose body is it anyway? Trading the dead poor, coroner's disputes, and the business of anatomy at Oxford University, 1885-1929', Bull. Hist. Med., 2008, 82: 775-819; and idem, Dying for Victorian medicine: English anatomy and its trade in the dead poor, 1870 to 1929, Basingstoke, Palgrave Macmillan, forthcoming; Fiona Hutton, 'The working of the 1832 Anatomy Act in Oxford and Manchester', Family and Community History, 2006, 9: 125-39; M H Kaufman, 'Transfer of bodies to the University of Edinburgh after the 1832 Anatomy Act', J. R. Coll Physicians Edinb., 2004, 34: 228-36; MacDonald, op. cit., note 5 above; idem, 'Possessing Bodies',

Meanjin, 2007, 66: 88-98; idem, Possessing the dead: the artful science of anatomy, Carlton, Melbourne University Press, forthcoming; idem, 'A body buried is a body wasted': the spoils of human dissection', in Sarah Ferber and Helen MacDonald (eds), The body divided, Aldershot, Ashgate, forthcoming; Anna Stevenson, 'An obscure personality called William Roberts: the later history of the Anatomy Act of 1832', BSc dissertation, History of Medicine, University of London, 2004. For the US, see Michael Sappol, A traffic of dead bodies: anatomy and embodied social identity in nineteenth-century America, Princeton University Press, 2002; for Australia, see Helen MacDonald, 'A scandalous Act: regulating anatomy in a British settler colony', Soc. Hist. Med., 2007, 20: 39-56; idem,

" "Humanity's discards": the New South Wales Anatomy Act, 1881', Mortality, 12: 365-82; and idem, 'The anatomy inspector and the government corpse', History Australia, forthcoming. For Vienna, see Tatjana Buklijas, 'Cultures of death and politics of corpse supply: anatomy in Vienna, 1848-1914', Bull. Hist. Med., 2008, 82: 570-607. 


\section{Helen MacDonald}

each body from place of death, through medical school, to the grave. He then set about the business of convincing parish Guardians and hospital officials to, as he called it, comply with the Act. For this, he needed all his powers of persuasion, since the statute compelled neither parishes nor hospitals to hand over their unclaimed dead. Somerville's letters were therefore carefully crafted to convince them to do so, and he darkly warned parishes of what might happen should the Anatomy Act fail: the "horrid traffic of body-snatching, and the more appalling crime of "burking""—or murder—would reappear. ${ }^{23}$

During the early years of the inspectorate, some schools continued to turn to the graverobbers, their customary source for obtaining subjects. ${ }^{24}$ In 1832 two men were committed for trial for resurrecting a body that was rumoured to be destined for St Bartholomew's Hospital school; the burial ground at Guy's Hospital school was raided and a corpse removed; and in 1834 some practised body-snatchers, now in the employ of the sexton of Chelsea parish, were caught offering bodies to the London schools. ${ }^{25}$ In that year, Somerville also hurried to investigate activities at an anatomy school in Hull, where he found that local people had daubed the walls with the words "Burkers" and "Chicken-shop". The school premises contained several bodies that had been unlawfully obtained, including the upper half of a young child. ${ }^{26}$

Somerville's priority was to prevent grave-robbing, but he had to achieve this in the context of the schools' urgent need of corpses. Thus he soon found his role extending beyond its legislative limitations, and became involved in sourcing and overseeing the distribution of bodies. As Durey notes, the inspector's powers were "ludicrously insufficient" for this task. ${ }^{27}$ It included inducing officials to send corpses to the schools and then attempting to ensure their equitable distribution, during a decade in which both private and hospital-based schools existed in London, competing viciously against each other to obtain subjects for their fee-paying students to dissect. ${ }^{28}$ To add to Somerville's problems, the hospital schools more readily obtained supplies for themselves. They offered deals to local parish officials to provide workhouse inmates with free hospital treatment in exchange for corpses from their dead houses. ${ }^{29}$ Several agreed; this arrangement saved the parish both the cost of medical treatment and the cost of funerals.

In fact, some hospital schools acted as if the inspector's office was an irrelevance. Between 1832 and 1844, corpses were openly purchased. Teachers at St Bartholomew's Hospital school routinely directed workhouse and prison officials to send bodies to them, paying $£ 5$ per corpse and overriding the inspector's instructions

\footnotetext{
${ }^{23}$ Quotation from letter from magistrates Thomas Walker and J Harwick, The Times, 21 Nov. 1834, p. 1.

${ }^{24}$ Durey notes that there were only isolated cases in London, but that grave-robbing remained a problem in the provinces throughout the 1830s: op. cit., note 22 above, pp. 211, 219-20.

${ }^{25}$ National Archives, Kew (hereafter NA), MH $74 / 12$, letter from Somerville to Helps, 24 Nov. 1832, p. 45; letter from Somerville to Commissioners for Police, 28 Dec. 1832, p. 55; letter from Somerville to S M Phillipps, Permanent Under-Secretary at the Home Office, 28 Jan. 1834, p. 135.
}

\footnotetext{
${ }^{26}$ NA, MH 74/12, letter from Somerville to Phillipps, 5 June 1834, p. 148, Richardson op. cit., note 4 above, p. 263.

${ }^{27}$ Durey, op. cit., note 22 above, p. 219

${ }^{28} \mathrm{By}$ the 1840 s, the private schools had amalgamated with the larger schools, or closed. For their demise, see Adrian Desmond, The politics of evolution: morphology, medicine, and reform in radical London, University of Chicago Press, 1989.

${ }^{29} \mathrm{NA}, \mathrm{MH} 74 / 12$, letter from Somerville to Phillipps, 15 Apr. 1834, p. 145.
} 
that they be sent elsewhere. ${ }^{30}$ This was not illegal, for nothing in the Anatomy Act had banned such sales. ${ }^{31}$ But these payments resulted in some parish officials collecting bodies with such zeal that illegalities soon followed. Bodies claimed by relatives for burial were instead sold for dissection. ${ }^{32}$ All in all, Somerville was soon reporting to the Home Office that his job had become "one continued struggle ... to enforce the regulations". ${ }^{33}$ The exchange of money for corpses was turning parish officials into "Traffickers in Dead Bodies", and the inspector warned that prices might spiral to such an extent that "the field would again be thrown open to the Resurrectionists $\&$ to all the horrors which once existed". ${ }^{34}$

Faced with constant criticism from the medical schools of his inability to provide them with sufficient corpses, Somerville came to condone, even promote, evasions of the law whose provisions he was meant to administer, not least that section which enabled family members to claim bodies and prevent them being dissected. Somerville suggested ways in which anatomy teachers could obtain and use human remains without relatives being any the wiser. For example, they could persuade workhouse masters to send them bodies by guaranteeing to subject these to a quick, minimal dissection-of the viscera onlybefore sending them back to the workhouse for burial without obvious disfigurement (at least to a relative who did not insist on the body being taken from its coffin and its shroud removed). ${ }^{35}$ Somerville also showed the teachers other ways to disguise the fact that a dissection had taken place. In 1834 he asked three London anatomy teachers to send him an extract from the Parish Register of Burials, "without any observation as to the Body having been examined at your School", rather than specific certificates of interment, for relatives might request to see these documents. ${ }^{36}$ A third deception lay in the fact that Somerville encouraged everyone concerned with the transfer of bodies to act with the utmost discretion, in the hope that no scandal would result-for if it did, a diminution of supplies would quickly follow. ${ }^{37}$

\section{After Somerville: The Anatomy Inspectors and Presumed Consent to Dissection}

In 1842, James Somerville was relieved of his duties in a highly charged atmosphere. Surgeon William Roberts, a constant critic of the Anatomy Act, had petitioned parliament to investigate the working of the Act. He and others claimed that Somerville

\footnotetext{
${ }^{30}$ NA, MH 74/12, report from Somerville to Phillipps, 12 Jan. 1835, p. 175.

${ }^{31}$ The parliamentary debates reveal that those promoting the bill wished to reduce the cost of corpses, rather than ban their sale. As Richardson has shown, given Wakley's long campaign in the pages of the Lancet to prohibit commercial dealings with the dead, this omission from the Act was unlikely to have been accidental. Richardson, op. cit., note 4 above, p. 249.

${ }^{32}$ NA, MH 74/12, report from Somerville to Phillipps, 12 Jan. 1835 , p. 175. See also The Times, 21 Nov. 1834, p. 1.
}

\footnotetext{
${ }^{33}$ NA, MH 74/12, letter from Somerville to Phillipps, 9 Oct. 1834, p. 164.

${ }^{34}$ NA, MH 74/12, report from Somerville to Phillipps, 12 Jan. 1835, p. 175.

${ }^{35}$ NA, MH 74/12, letter from Somerville to Teale, 5 Nov. 1832 , p. 41.

${ }^{36}$ NA, MH 74/12, letter from Somerville to Partudy, Stanley and Grainger, 19 Mar. 1834, p. 138.

${ }^{37}$ Richardson has argued that during Somerville's term, the public knew that unclaimed bodies were sent to be dissected, but was unaware of the routine means through which this was effected, as these were secretive: op. cit., note 4 above, p. 252.
} 


\section{Helen MacDonald}

was partial in his distribution of corpses, that he threatened teachers who complained, and that he sanctioned the burial of dissected remains in unconsecrated ground. ${ }^{38}$ The Secretary of State, Sir James Graham, appointed two commissioners to examine Somerville's conduct. They heard no evidence, and their report was not presented to parliament, but Somerville was dismissed. ${ }^{39}$

Following Somerville's departure, the anatomy inspectorate was reorganized. In England responsibility was divided. Military surgeon (John) Rutherford Alcock replaced Somerville to become the metropolitan inspector, while John Bacot assumed the responsibility of the provinces. ${ }^{40}$ Two years later, when Alcock retired to take up a diplomatic post, Bacot succeeded him in the metropolitan role and Dr George Cursham became the provincial inspector for England and Wales. ${ }^{41}$ During these men's terms in office, from 1842 until 1858, the inspectorate records reveal how the evasive activities that had been set in motion during Somerville's time became an established pattern of behaviour, violating the inspectors' statutory role of administering the legislation, not least the clause that enabled individuals or their relatives to dissent from dissection.

Inspector Alcock set about the business of ensuring that silence surrounded the working of the Act. He read Somerville's records and quickly understood the difficulties that confronted his predecessor. Alcock wrote to all the metropolitan and provincial anatomy teachers to explain the inspectors' duties under the Anatomy Act. These did not include obtaining and distributing bodies, but rather the removal of obstacles to their supply and distribution. The Act limited the inspectors' role to protecting the study of anatomy, preventing the committing of crimes, and guarding against any "outrage to the feelings of the community". Alcock reported to the Home Office that this was how the provincial inspector's role worked, with the teachers finding their own corpses. ${ }^{42}$ Things were different in London. There, the teachers now expected the inspector to resolve their difficulties in obtaining supplies, even though, as Alcock wrote to Anthony White, president of the Royal College of Surgeons, the inspectors were not empowered to do so under the act and "without Power there can be no responsibility". 43

\footnotetext{
${ }^{38}$ Stevenson, op. cit., note 22 above, pp. 24-5. On Roberts, see also Durey, op. cit., note 22 above, pp. 212-17, and Richardson, op. cit., note 4 above, pp. 246-50.

${ }^{39}$ Stevenson, op. cit., note 22 above, p. 32.

${ }^{40}$ Alcock, an FRCS, had trained at Westminster Hospital and the Royal Westminster Ophthalmic Hospital, before serving as a house surgeon at the Westminster Hospital, then obtaining military postings abroad. He returned to England in 1838, and was a lecturer in surgery at Sydenham College before taking up the position of anatomy inspector. A muscular problem with his hands brought to an end his surgical career. R K Douglas, 'Alcock, Sir (John) Rutherford (1809-1897)', rev. J A G Roberts, Oxford Dictionary of National Biography, Oxford University Press, 2004, vol. 1, pp. 500-601, and http://www. oxforddnb.com/view/article/293. John Bacot (1781-1879), MRCS, FRCS, had trained at St George's Hospital and had also been an army doctor, as well as a surgeon to St George's Hospital
}

and the St James' Dispensary. He was one of the first members of the Senate of the University of London. After a period in private practice, Bacot joined the inspectorate: Plarr's Lives of the Fellows Online, http://livesonline/rcseng.ac.uk/biogs/E000471b.htm. He retired from it in 1858 .

${ }^{41}$ Alcock became British consul at Foo-Chow-foo (NA, MH 74/15, letter from Alcock to Phillipps, 17 June 1844, p. 124). George Cursham, MD, FRCP, had been a physician to the Brompton Hospital and the Asylum for Female Orphans in London before his appointment as provincial inspector, which he held until his death. 'George Cursham, MD, FRCP', Br. Med. J., 1871, ii: 424 .

${ }^{42} \mathrm{NA}, \mathrm{MH} 74 / 15$, letter from Alcock and Bacot to metropolitan and provincial teachers, 18 Oct. 1842, p. 5; report from Alcock to Phillipps, 7 Mar. 1843, p. 60 .

${ }^{43}$ NA, MH 74/15, letter from Alcock to White, 6 Dec. 1842 , p. 21. 


\section{The English Anatomy Inspectorate, 1842 to 1858}

Alcock strongly believed that to be successful in increasing the number of parishes that complied with the act, the anatomy inspector's work must be performed invisibly. He advocated working behind the scenes, so that the inspector's influence was seen only by results. ${ }^{44}$ His strategy for achieving this end further decreased workhouse inmates' ability to protest against being dissected. Somerville had sought corpses from parishes by directly requesting the Boards of Governors and Guardians, who had legal custody of the bodies, to comply with the Anatomy Act. This direct approach, Alcock informed the Secretary of State, meant that dissection was raised "as a matter of business" while the Guardians were "collectively assembled", and so attracted hostile discussion. To make matters worse, the subject was further publicized, since the parish clerks sent written notice of the proceedings to all the Board members. Alcock disapproved of this procedure. Dissection, he knew, was a subject which even those most favourable to the aims of the act "very decidedly" shrank from supporting in public. ${ }^{45}$

Alcock's lack of sympathy for the direct approach rested on his understanding of popular sentiment. Knowing that many people believed, with The Satirist, that consigning pauper bodies to dissection was carrying "the principle of poor-law administration to an extent not contemplated by the most rigid economist", Alcock considered that an official approach to parishes could only result in mischief. ${ }^{46}$ Nor did he make use of the assistant commissioners who had been appointed under the New Poor Law legislation from 1834. Rather, the anatomy inspectors negotiated and communicated directly but strategically with unions and parishes. ${ }^{47}$ Alcock personally contacted local men, first informally "sounding out" the chairman, clerk, and such individual members of a Board of Guardians with whom he was acquainted. ${ }^{48}$ In particular, he understood that parish medical officers were likely to be sympathetic to the medical schools' plight. ${ }^{49}$ In 1842, for example, Alcock sought assistance from the medical officer of Hackney Union, explaining that from "apathy, indifference, or occasionally prejudice, in those authorities who have the legal custody of the unclaimed Poor", large numbers of bodies were being buried rather than dissected. As Alcock pointed out, this was both "to the pecuniary disadvantages of the parishes and the injury of Science". 50 When John Bacot succeeded Alcock in 1844 he continued to employ these cautious tactics in obtaining workhouse bodies. Bacot first approached parish medical officers ("whose aid I look upon as certain") for their advice about which influential local people he should contact, and only after these had been consulted did he write to the Board of Guardians formally to request that the parish comply with the act. ${ }^{51}$

Despite such precautions, problems could still arise. If, for example, the inspectors learned of a parish, such as St Giles, which customarily invited relatives to attend a workhouse resident's burial, the inspectors worked hard to overturn that practice as

\footnotetext{
${ }^{44} \mathrm{NA}, \mathrm{MH} 74 / 15$, report from Alcock to

Phillipps, 7 Mar. 1843, pp. 72-3.

${ }^{45}$ Ibid., pp. 71-2.

${ }^{46}$ The Satirist; or, the Censor of the Times, 13 Feb. 1842, p. 55.

${ }^{47}$ NA, MH 74/15, letter from Bacot to Sir George Cornewall Lewis, 28 Nov. 1849, p. 282.
}

\footnotetext{
${ }^{48}$ NA, MH 74/15, report from Alcock to Phillipps, 7 Mar. 1843, pp. 71-2.

${ }^{49}$ Ibid., p. 72.

${ }^{50}$ NA, MH 74/15, letter from Alcock to Howell, 11 Nov. 1842, pp. 11-12.

${ }^{51}$ NA, MH 74/15, letter from Bacot to Benjamin Alcock, Sep. 1853, pp. 337-8.
} 


\section{Helen MacDonald}

it effectively removed these bodies from the chain of supply. ${ }^{52}$ Provincial inspector George Cursham sympathized with anatomy teachers who wrote to him complaining that the poor were joining burial societies which claimed their bodies and interred them when they died. One medical man, Dr Embledon of the Newcastle anatomical school, had been about to dissect a corpse when a burial society representative claimed it from him. Embledon wrote angrily to Cursham, who advised him to "yield" the body in order to avoid exciting public attention-even though burial societies had no legal power to prevent a dissection. ${ }^{53}$ Cursham also thoroughly disapproved of the hospital house surgeon in Manchester who insisted that notices be pasted up in the hospital wards to alert patients to the Anatomy Act's provisions, and so enable them to make formal declarations that they wished to go to the grave in one piece. In Inspector Cursham's view, this was "very unbecoming" conduct in any professional man. ${ }^{54}$

In trying to ensure that these stealthy practices were not discovered, the inspectors were also involved in other deceptions. When Bacot, for example, learned that relatives had arrived at King's College medical school to claim a body that was being dissected there, he rushed to stop the dissection. The school was told to bury the corpse quickly, and to ensure that the certificate sent to his office made it appear that the body had been sent to the grave through "the ordinary channel"- that is, directly from the workhouse. ${ }^{55}$ And when Henry Wilson's mother informed the governor of the House of Correction at Wandsworth, where her son had died, that she would attend his funeral, the inspector instructed the school to which Wilson's body had already been sent not to touch the face, and to return the corpse immediately. Thus Henry Wilson's mother was deceived into believing that her son was being buried in the ordinary way. ${ }^{56}$

\section{Escaping the Act: Body Parts}

The Anatomy Act only concerned itself with whole corpses. Medical schools did not need to account to the inspectorate for such body parts that they managed to procure. The legislative omission was odd, given that the statute had been designed to deter grave-robbing and murder, for such activities were difficult to detect on corpses sold as dismembered parts. For this reason, the ease with which grave-robbing and murder might continue after 1832 had been a matter of concern during the debates on the Anatomy Bill. One creative solution had been suggested by a certain Mr Sewell, who argued that no limb should be accepted for dissection unless it arrived at the school indelibly branded with the person's identity. ${ }^{57}$ Nevertheless, the legislation made no reference to body parts, and this set many of the schools' activities beyond its remit,

\footnotetext{
${ }^{52}$ NA, MH 74/15, report from Alcock to Phillipps, 7 Mar. 1843, p. 67.

${ }^{53}$ NA, MH 74/10, letter from Cursham to Embledon, 12 Jan. 1850 , p. 80.

${ }^{54} \mathrm{NA}, \mathrm{MH} 74 / 10$, letter from Cursham to Key, 8 Jan. 1856, p. 195.
}

\footnotetext{
${ }^{55} \mathrm{NA}, \mathrm{MH} 74 / 15$, letter from Eubank to Ashton, 2 Jan. 1850, pp. 291-2.

${ }^{56}$ NA, MH 74/15, letters from Gregg to Onslow, 1 Dec. 1855, p. 386; from Bacot to Deville, 1 Dec. 1855, p. 386; from Gregg to Shew, 17 Dec. 1855, p. 388.

${ }^{57}$ The Times, 10 Dec. 1831 , p. 3.
} 


\section{The English Anatomy Inspectorate, 1842 to 1858}

both when dismenbered body parts were delivered to the schools, and when specimens were cut out of bodies during dissection and retained rather than being sent for burial. ${ }^{58}$

The inspectors feared that scandal would erupt if the public learned that body parts were arriving in dissecting rooms unaccompanied by documentation certifying a natural cause of death or that the corpse had lawfully been made available for dissection. They tried to prevent the acquisition and use of body parts, even though they had no powers to do so. When in 1868 one Mr Bradford asked Inspector Hawkins in a matter-of-fact way to inform him of the going rate for an "upper extremity", Hawkins icily responded that, "this is an arrangement which I have nothing to do [with], it rests entirely with the different Schools". ${ }^{59}$ When the Royal College of Surgeons requested Inspector Alcock to send them two heads, he pointed out that he was not empowered to authorize the dismemberment of human bodies. ${ }^{60}$ The most the inspectors could do was to urge medical schools and individual medical men not to accept body parts or, if they did, to use their "utmost discretion". 61

\section{Selling Bodies}

Before 1844, no law prohibited workhouse masters from selling bodies to the medical schools. In answer to a parliamentary question raised in that year, the then Secretary of State, Sir James Graham, argued that profiting from corpses was not problematic, as such activities were restricted by the provision that paupers or their relatives could dissent from a body being dissected. ${ }^{62}$ However, William Roberts's ongoing campaign against the Anatomy Act had focused unwelcome publicity on how easily people's dissent could be elided when a corpse could be turned to profitable use, and the question could not be ignored. The Government succeeded in sidelining calls for a Select Committee that would expose the practice - and much else-by quietly adding a section to the Poor Law Amendment Act that was then passing through parliament. ${ }^{63}$ Under this statute it was no longer lawful for "any Officer connected with the Relief of the Poor" to "receive any Money from any Dissecting School or School of Anatomy, or Hospital, or from any Person or Persons to whom any such Body may be delivered, or to derive any personal Emolument whatever for or in respect of the Burial or Disposal of any such Body". The

\footnotetext{
${ }^{58}$ For a discussion of preparations and specimens in medical museums, see Samuel J M M Alberti, 'The museum affect: visiting collections of anatomy and natural history', in A Fyfe and B Lightman (eds), Science in the marketplace: nineteenth-century sites and experiences, University of Chicago Press, 2007, pp. 371-403; idem, 'Wax bodies: art and anatomy in Victorian medical museums', Mus. Hist. J., 2009, 2: 7-36; Simon Chaplin, 'Nature dissected, or dissection naturalized? The case of John Hunter's museum', Mus. Soc., 2008, 6: 135-51; Jonathan Reinarz, 'The age of museum medicine: the rise and fall of the medical museum at Birmingham's school of medicine', Soc. Hist. Med., 2005, 18: 419-37; and Elizabeth Hallam, The anatomy museum: death and the body displayed, London, Reaktion, forthcoming.

${ }^{59}$ NA, MH 74/6, Hawkins to Bradford, 18 Jan. 1868, p. 246.
}

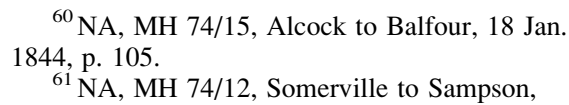

${ }^{61}$ NA, MH 74/12, Somerville to Sampson, 12 Oct. 1832, p. 28; Somerville to Barclay, 18 Oct. 1832, p.33; Somerville to Wheeler, 17 Oct. 1832, p. 32. As Elizabeth Hurren has shown for the Cambridge anatomical school later in the century, parts continued to be sought, especially when whole bodies were difficult to procure: Hurren, 'A pauper dead-house', op. cit., note 22 above, p. 83

${ }^{62}$ Parl. Debs. (series 3), vol. 75, col. 527, 13 May to 26 June 1844 (on 11 June 1844).

${ }^{63}$ For the way in which anatomy featured in the parliamentary debate, see Parl. Debs. (series 3), vol. 74, cols. 26-29, 15 Apr. to 24 May 1844 (on Apr. 1844 and 21 May 1844); vol. 75, cols. 523-34, 30 May to 26 June (on 11 June 1844 and 24 July 1844). 


\section{Helen MacDonald}

penalty for doing so would be, on conviction, a fine not exceeding five pounds. ${ }^{64}$ As always, however, legislation was one thing, its enforcement could be another. As an assistant Poor Law commissioner noted of his own attempts to implement a statute by banning the payment of outdoor relief to able-bodied men, such legal prohibitions might be "carried out to the letter" while being "paralysed as to the spirit". ${ }^{65}$ The Victorian inspectorates had varying powers to prosecute contraventions of the laws under which they were established, besides which, as Christine Garwood has argued with reference to the inspectors appointed under the Alkali Act of 1863, prosecution was generally left "as a distant threat and last resort measure". ${ }^{6}$ This was also true of the Anatomy Act. Though constantly contravened, no case was prosecuted under it until 1855, when surgeon Robert Parrot took possession of a corpse and cut into it in such bizarre circumstances that a conviction could hardly fail to be obtained. ${ }^{67}$ As for the 1844 amendment to the Poor Law legislation, an opportunity to prosecute workhouse master Alfred Feist under that law was missed in 1858 , as will be discussed below.

Despite the preference for avoiding prosecutions under these laws, the 1844 amendment to the Poor Law Act banning workhouse masters from selling bodies placed the anatomy inspectors in a difficult situation. They knew that workhouse officials and undertakers who were not paid for supplying the schools often declined to do so. When John Bacot next wrote begging them for corpses, they informed him that they might be able to send him some if they were paid "some trifling remuneration" in exchange. Bacot knew that the law now prohibited such transactions. ${ }^{68}$ Nevertheless, he of necessity found ways to do workhouse masters and undertakers "some little service" or give them "some trifling gratification", while denying any knowledge of the practice. ${ }^{69}$ Bacot obtained an additional $£ 100$ per annum from the Home Office to cover "certain expenses" to facilitate supply, and he was careful to describe these additional funds as enabling him to repay outlays incurred by "the parties removing the Subjects", rather than as bribes. The payments were necessary, he wrote to the Home Office, for he needed these men to be "vigilant and active" in the cause of supplying the schools. ${ }^{70}$

\section{The Anatomy Inspectorate and London's Undertakers}

In his discussion of the inspectorate's first decade, Durey briefly notes that undertakers were beginning to play a role other than the restrictive one given to them under the Act of burying remains, for Somerville's involvement in distributing corpses had greatly increased his workload and so he had begun to hire, supervise and finance undertakers to carry corpses. ${ }^{71}$ However, it was not until the later period examined here that undertakers became pivotal to the supply of material to London's medical schools.

\footnotetext{
64 'An Act for the further amendment of the laws relating to the poor in England', 9 August 1844, The statutes of the United Kingdom of Great Britain and Ireland, 7 \& 8 Victoria. 1844, London, Her Majesty's Printers, 1844, pp. 600-35, on pp. 611-12.

${ }^{65}$ William Day, cited in Michael Rose, The English Poor Law 1780-1930, Newton Abbot, David \& Charles, 1971, p. 126.

${ }^{66}$ Garwood, op. cit., note 9 above, p. 103.
} 


\section{The English Anatomy Inspectorate, 1842 to 1858}

When that happened, the inspectors became involved in practices that further worked against people's ability to dissent from dissection.

The Anatomy Act had excluded undertakers from having any role in procuring corpses, which meant that they were not responsible to the anatomy inspectorate. According to Inspector Alcock, they were "wholly irresponsible and without control". Yet undertakers were in an ideal position to provide corpses to the schools, for they were part of established parish networks, and a constant presence in the workhouses. Each parish contracted with an undertaker to bury its paupers, and the parishes that decided to comply with the Anatomy Act recommended their own undertakers for this additional and more lucrative work. In this way, and within the ongoing problem of subjects for dissection being in short supply, the anatomy inspectors were inevitably drawn into working with the trade. The inspectors well knew that undertakers would avidly seek to provide corpses, since their profits increased with the numbers procured. They also knew that if the undertakers were denied this role, they would become, in Inspector Alcock's words, powerful "enemies of supply". 72

Soon after his appointment as metropolitan inspector, Alcock employed a go-between in London, to set a distance between himself and this trade. He wrote to the Home Office of the importance of appointing a "fit person to superintend the removal of bodies etc.", an "expediter" upon whom much would depend. ${ }^{73} \mathrm{He}$ chose for this job $\mathrm{Mr}$ Hewett, the master at the Holborn Union Workhouse in Gray's Inn Lane, who came "well recommended for his zeal, integrity and judgement". ${ }^{74}$ Henceforth, Hewett would deal with the workhouse masters and undertakers in arranging the removal of corpses and their subsequent interment. ${ }^{75}$ If a parish insisted that their own undertaker be employed for the work, Alcock would write to remind them that undertakers were not accountable to the inspectorate, and that "grave instances" had resulted from such independent contract work. He then requested workhouse masters to instruct their undertakers to deal with the "respectable person" he had employed, for Mr Hewett was responsible to him. $^{76}$

By the 1850s, however, undertakers had become central to the supply and distribution of corpses to London's schools. Inspector Bacot sometimes employed them directly, asking them to "go round to each [parish and union] to ascertain what bodies can be obtained" ${ }^{77}$ The inspectorate records reveal that undertakers' activities extended far beyond simply finding and carting bodies to the schools. They entered institutions' dead houses and personally assessed, on the inspectors' behalf, the suitability of particular bodies for a school's requirements-as when the Royal College of Surgeons ordered three male corpses for its Fellowship examinations; and when a school issued a demand through an undertaker for "a male subject by tomorrow". Some requests were so specific that they could not be met even by the most eager of undertakers. When

\footnotetext{
${ }^{72} \mathrm{NA}, \mathrm{MH} 74 / 15$, report from Alcock to Phillipps, 7 Mar. 1843, pp. 53, 61, 67.

${ }^{73}$ NA, MH 74/15, report from Alcock and Bacot to Phillipps, 6 Oct. 1842, p.2.

${ }^{74}$ NA, MH 74/15, report from Alcock and Bacot to Phillipps, 4 Nov. 1843, p.54.
}

\footnotetext{
${ }^{75} \mathrm{NA}, \mathrm{MH} 74 / 15$, letter from Alcock to Ellis, 20 Oct. 1842 , p. 7.

${ }^{76} \mathrm{NA}, \mathrm{MH} 74 / 15$, letter from Alcock to Governors and Guardians of St Mary Newington, 8 Nov. 1842, p. 9.

${ }^{77} \mathrm{NA}, \mathrm{MH} 74 / 15$, report from Bacot to Phillipps, 5 Jan. 1846, p. 179.
} 


\section{Helen MacDonald}

St Bartholomew's Hospital school asked for a "fine young Male body", the inspector's clerk tartly responded, "We cannot kill fine young men". 78

Inspector Bacot defended his reliance on undertakers on the grounds that it was impossible for one London inspector to administer the Anatomy Act in the city. This was precisely what critical parliamentarians had claimed would be the case during the debates of 1831-2. In 1857, when University College medical school complained to Bacot about the poor condition of a cadaver received from Millbank Prison, the inspector querulously responded that he was unable to assess the condition of each body sent to a school. To do so would require "a large class of Inspectors" given that bodies were sent "at uncertain times from nearly forty different sources" across the metropolis. ${ }^{79}$

The inspectors now relied upon undertakers to make such assessments for them. Bacot's clerk instructed undertaker John Dix to personally examine each corpse before he delivered it to a medical school, and to refuse to accept those that were unsuitable for dissection. He warned Dix that all hospital bodies should be treated with "suspicion" as they had probably already been subjected to an extensive post-mortem examination. ${ }^{80}$ Here again, the inspectors were in a difficult situation. The Anatomy Act did not regulate hospital post-mortems, but the inspectors knew that when hospital bodies arrived in the schools, they could be useless for the purpose of dissection, and might be angrily rejected both by the school and by the medical students whose fees had bought them no more than a worthless corpse. Unwilling to oversee a system in which mutilated bodies were travelling back and forth between hospitals and schools, the inspectors turned to the undertakers for a solution. Bacot instructed undertaker Harwell to look closely at each corpse before he removed it. If it was "merely opened" it could be taken to a school, but "if all the parts are taken out, or the body [is] covered with ulcers and slough" the corpse was to be rejected as of no possible use. ${ }^{81}$

Knowing the extent to which both the anatomy inspector and the medical schools depended upon them, London's undertakers frequently ignored the Anatomy Act's provisions, not least the supposedly protective dissent clause. They delivered bodies to the schools without the accompanying medical certificate that was one of the act's "most stringent requirements", being meant to provide some certainty that the person's death had been natural. ${ }^{82}$ In addition, they carted corpses to dissecting rooms too expeditiously, before the forty-eight hour period during which relatives could claim the body had passed. ${ }^{83}$ The undertakers also usurped the inspectors' authority by ignoring their instructions about which school should receive particular corpses, making the decisions themselves, in an economy of corpses in which some bodies were more valuable than others. $^{84}$ "I am surprised to find", Bacot wrote to undertaker Johnes in 1855, "that in

\footnotetext{
${ }^{78} \mathrm{NA}, \mathrm{MH} 74 / 15$, letter from Eubank to Dix, 30 Nov. 1849, p. 286; letter from Gregg to Hogg, 29 May 1855, p. 366; letter from Gregg to Holden, 5 Nov. 1856, p. 416.

${ }^{79} \mathrm{NA}, \mathrm{MH} 74 / 15$, letter from Bacot to Ellis, 14 Oct. 1857, p. 453.

${ }^{80}$ NA, MH 74/15, letter from Eubank to Dix, 26 Jan. 1850, p. 298. For hospital post-mortems, see MacDonald, Possessing the dead, op. cit., note 22 above.
} 


\section{The English Anatomy Inspectorate, 1842 to 1858}

defiance of all I can say, you still persist in doing as you please with the subjects you procure" ${ }^{85}$ This was not the first time that Bacot had found Johnes acting in underhand ways. The undertaker had earlier been involved in "surreptitiously" removing a corpse from the Whitechapel Union, with the assistance of a "simulated relation" and bogus paperwork, and taking it to the London Hospital medical school. ${ }^{86}$

\section{Trafficking in the Dead}

Just how vigilant and active undertakers and workhouse masters could be in sourcing corpses for the schools was revealed in 1857-8, during a scandal which culminated in the second case to be prosecuted under the Anatomy Act. Alfred Feist, master of the St Mary Newington workhouse, was accused in the Central Criminal Court of unlawfully disposing of pauper bodies to Guy's Hospital medical school. He and the parish undertaker, Robert Hogg, had turned the workhouse into a place where corpses were processed into profitable objects. At any given time, the dead house contained workhouse bodies and others brought in from elsewhere, as well as coffins containing dissected remains that had been removed from Guy's for burial. The men's resourceful system for turning these remains to good account was relatively simple. On the morning of a workhouse inmate's burial, after a relative (usually a daughter or sister) had viewed the body, she was sent from the dead house to the waiting room while Hogg or Feist nailed down the coffin lid. A little later, she was called and told to step into the funeral carriage, while the undertaker's men lifted a coffin into the accompanying hearse. That coffin contained a stranger's dissected remains. While the relative accompanied this coffin to the burial ground to witness what she thought was a family member's interment, Feist filled in the notice that made that corpse available for dissection. Hogg then took the notice to Inspector Bacot, and received in return a warrant that authorized the body to be taken to Guy's. 87

This scandalous case was reported extensively in the English newspapers. It revealed to the public how workhouse inmates' and their relatives' right to dissent from dissection was being routinely undermined, and how ineffective the anatomy inspectorate was in preventing this. Feist was convicted of unlawfully disposing of the dead, but the decision was later overturned on the grounds that the Anatomy Act gave workhouse masters lawful possession of corpses, even though workhouses were not mentioned in the statute. ${ }^{88}$ Despite the long-held common law principle that there was no property in the human

Dix, 19 Jan. 1855 , p. 355 ; letter from Gregg to Dix, 9 Feb. 1855 , p. 356.

${ }^{85}$ NA, MH 74/15, letter from Bacot to Johnes, 8 Jan. 1855 , p. 353.

${ }^{86}$ NA, MH 74/15, letter from Bacot to Adams, 14 Jan. 1850, p. 293, and letter from Bacot to Smith 21 Jan. 1850, p. 296.

${ }^{87}$ Southwark Local History Library, Parish of St Mary Newington, 'Legal Papers about the Indictment of Alfred Feist, Workhouse Master, for the Removal of Paupers' Bodies to Guy's
Hospital School of Anatomy, 1858'. 'Lambeth Police Court, Monday 20 January' and 'Copy of evidence taken by Mr Farnall, Poor Law Inspector, on 22 January 1857'. See MacDonald, 'Possessing bodies', and Possessing the dead, both cited in note 22 above.

${ }^{88} R$. v. Alfred Feist (1858), see Henry R Dearsly and Thomas Bell, Crown cases reserved for consideration, and decided by the judges of England, London, Stevens \& Norton; H Sweet \& W Maxwell, 1858 , p. 1135. 


\section{Helen MacDonald}

corpse, the Anatomy Act had created a limited right to possess one, and workhouse masters had acquired this right. ${ }^{89}$ The court decided that Feist had not acted unlawfully in sending these corpses to a school, for no one had effectively dissented to their dissection. The fact that the relatives believed that they were claiming the bodies by seeing them interred counted for nothing. As one judge explained, Feist had been charged under the wrong law if the intention had been to convict him of selling corpses, for the Anatomy Act did not ban him from doing so. ${ }^{90}$ He should instead have been charged under the Poor Law Amendment Act (1844), which did. Had that been the case, $R$. v. Feist might have brought such sales to a halt. As things stood, pauper cadavers were still being sold decades later, as Elizabeth Hurren has shown for the Cambridge and Oxford medical schools. ${ }^{91}$

Anatomy Inspector Bacot soon felt the effects of this scandal. London's workhouse officials took fright and stopped complying with the Act. As a result, the schools wrote to complain about the shortage of corpses; even Guy's Hospital medical school, which had been implicated in the scandal, registered concern. Bacot's clerk responded by claiming that the sudden shortage was due to that school's own "great want of caution and prudence", and informed them that the inspector feared that "some time must elapse before the prejudice which now exists in the minds of the public can be removed". ${ }^{92}$ In his next quarterly report to the Home Office, Bacot tried to argue that the extreme shortage of corpses had come about because paupers were unusually healthy for this time of the year. He tried to deflect personal censure for the scandal, assuring the Home Office that no irregularity could be traced to his office, "where all the papers connected with the removals of the subjects from Newington are perfectly correct". In addition, Bacot claimed that in making copies of these documents available to the parish church wardens, he had assisted in "bringing the guilt of these transactions upon the offending parties", showing "the strictness with which the duties of my office have been performed". 93

Bacot's plea was to no avail. The following month he was replaced by a new inspector, Charles Hawkins, who received an apparently strict set of instructions from the Home Office about how he was to perform the inspector's role. ${ }^{94}$ These included

\footnotetext{
${ }^{89}$ The Anatomy Act joined other limited, non-proprietary rights in a corpse that were recognized in law, notably the duty to bury it. For a discussion, see Rohan Hardcastle, Law and the human body: property rights, ownership and control, Oxford and Portland, OR, Hart Publishing, 2007, pp. 46-53, and Daniel Sperling, Posthumous interests: legalethical perspectives, Cambridge University Press, 2008, pp. 94-5. Prior to the Anatomy Act, the law also held that a dead person could not dispose of his corpse via a testamentary declaration, although utilitarian philosopher Jeremy Bentham notably had: Ngaire Naffine, 'When does the legal person die? Jeremy Bentham and the "Auto-Icon", Aust. J. Legal Philos., 2000, 25: 79-95.

${ }^{90}$ Dearsly and Bell, op. cit., note 88 above, p. 1135 .
}

\footnotetext{
${ }^{91}$ Hurren, 'A pauper dead-house' and 'Whose body', both cited in note 22 above.

${ }_{92} \mathrm{NA}, \mathrm{MH} 74 / 15$, letter from Gregg to Brown, 14 Dec. 1857 , p. 462.

${ }^{93} \mathrm{NA}, \mathrm{MH} 74 / 15$, report from Bacot to

Waddington, 4 Jan. 1858, pp. 465-6.

${ }^{94}$ Charles Hawkins, MRCS, had trained at St George's Hospital. He assisted surgeon Sir Benjamin Brodie, later becoming Brodie's close friend and editor of his collected works. Hawkins was a Fellow of the Royal Medical and Chirurgical Society. He served St George's Hospital throughout his life, becoming its treasurer and vice-president, and he also sat on the Council of the Royal College of Surgeons. Lancet, 30 April 1892, i: 1004.
} 


\section{The English Anatomy Inspectorate, 1842 to 1858}

the instruction immediately to report to the Home Office any wilful contravention of the Act. ${ }^{95}$ In practice, however, the new inspector found himself as dependent on workhouses and undertakers as his predecessor had been. The Home Office might insist that things must change, but no inspector could afford to remonstrate too severely with his sources of supply. Within eight days of receiving those instructions, Hawkins was experiencing this dilemma at first hand. He had learned that undertaker John Dix had obtained five workhouse bodies and taken them to schools of his own choosing, with none of the accompanying paperwork that made such transactions lawful, and without which the anatomy inspector had no way of knowing that the deaths had been natural or the corpses unclaimed. This was surely wilful disobedience of the law, of the kind that the Home Office had insisted must be reported to them. Hawkins made no such report. Instead, the new inspector wrote to reassure Dix that, although he had been instructed to see that the Anatomy Act's requirements were carried out and wanted those pieces of paper, he had no wish unnecessarily to interfere in Dix's removal of bodies, or to give him more trouble than was absolutely essential. $^{96}$

\section{Conclusion}

The certificates, notices and warrants that had been designed to safeguard against the unlawful acquisition of bodies by England's medical schools in reality provided no such guarantees. They did, however, enable the anatomy inspectors to claim, when a scandal arose, that no wrongdoing could be traced to their office. In this article's opening vignette, the Lancet's insistence that the mutilated remains discovered in the Thames could not have come from a dissecting room, given the inspectors' stringent oversight of the Anatomy Act, flew in the face of this reality. When Inspector Hawkins was drawn into that discovery, he could plausibly deny any knowledge of the corpse, on the grounds that no paperwork existed for it.

The practices that developed under the British Anatomy Act over the period 1842 to 1858 reveal that, far from safeguarding individuals from being dissected against their own or their relatives' wishes, the anatomy inspectors lacked the power to play such a protective role. Instead, they came to act as impediments to people's right to dissent. The inspectors could not be faithful to the law which they embodied, and were complicit in the contraventions of others, because they worked at a time when the study of anatomy, learned hands-on by dissection, was a crucial part of medical education, and when few corpses arrived at the schools by donation. Without a staff adequate to the demands of the law, and facing an unrelenting demand for subjects, the inspectors found themselves working outside the formal parameters of their role, and allowing evasions of the law. Just how far this confluence of factors might go was revealed during the 1858

\footnotetext{
${ }^{95} \mathrm{NA}, \mathrm{MH} 74 / 36$, letter from Waddington to Hawkins, 17 Feb. 1858.
}

\footnotetext{
${ }^{96}$ NA, MH 74/6, letter from Hawkins to Dix, 25 Feb. 1858, pp. 4-5.
} 


\section{Helen MacDonald}

prosecution of the Newington workhouse master, which showed how perceptive the Anatomy Act's critics had been twenty-five years earlier. $R$. v. Feist clarified something that these critics had readily foreseen: that if England's anatomy inspectors were little more than paper tigers, the field would be left open for those who were in lawful possession of corpses, and others, to traffic in the dead. 